\title{
GOLM1 wt Allele
}

National Cancer Institute

\section{Source}

National Cancer Institute. GOLM1 wt Allele. NCI Thesaurus. Code C71022.

Human GOLM1 wild-type allele is located in the vicinity of $9 q 21.33$ and is approximately $74 \mathrm{~kb}$ in length. This allele, which encodes golgi membrane protein 1, plays a role in the mediation of posttranslational protein transport. The gene is expressed at elevated levels in the liver after viral infection and during hepatocellular carcinoma. 